\title{
Az első 200 transzkatéteres aortabillentyứ-implantáció a Gottsegen György Országos Kardiológiai Intézetben
}

\author{
Fontos Géza dr. ${ }^{1}$. Dékány Gábor dr. ${ }^{1}$ - Hegedüs Nikolett ${ }^{1}$ \\ Piróth Zsolt dr. ${ }^{1}$ - Amit Kumar Chaurasia dr. ${ }^{1}$. Pál Mátyás dr. ${ }^{1}$ \\ Mandzák Adrienn dr. ${ }^{1}$. Takács Viktor ${ }^{2}$ - Varga Andrea dr. ${ }^{1}$ \\ Kovács Attila dr. ${ }^{1}$ - Szabó György dr. ${ }^{1}$ - Andréka Péter dr. ${ }^{1}$ \\ ${ }^{1}$ Gottsegen György Országos Kardiológiai Intézet, Budapest \\ ${ }^{2}$ Medtronic Hungaria Kft., Budapest
}

\begin{abstract}
Bevezetés: Napjainkban a súlyos panaszos aortastenosis kezelésében a transzkatéteres billentyúimplantáció a sebészi billentyứcsere elérhető alternatíváját jelenti sebészi kontraindikáció és elfogadhatatlanul magas mütéti kockázat esetén. A szerzők intézetében ez a beavatkozás ma már a mindennapi rutin részének számít. Célkituzés: A szerzők az első 200, transzkatéteres billentyúimplantációban részesült beteg eredményeit tárgyalják. Módszer: 2016. januárig 200 sikeres implantáció történt. A betegek 55\%-a nő, átlagéletkoruk 79,9 év volt, az átlagos EuroSCORE: 19,3\%, az átlagos ejekciós frakció: 54\%, az aortabillentyün mérhető csúcsgradiens 81,2 Hgmm, az átlaggradiens: 50,9 Hgmm volt. Eredmények: A beavatkozásokat 99\%-os sikeraránnyal végezték, a szövődmények feldolgozása a VARC-2 kritériumrendszer alapján történt. Az egy hónapos mortalitás 5\%, az egyéves pedig 17,4\% volt, utóbbiból a kardiális mortalitás 13,6\% volt. Az egyéves cerebrovascularis történések előfordulása 5\% volt. Az egyéves kontroll során a betegek 95\%-a NYHA I vagy II funkcionális állapotban volt. Következtetés: Az eredmények nem térnek el lényegesen a nemzetközi vizsgálatok eredményeitől. Orv. Hetil., 2016, 157(45), 1786-1792.
\end{abstract}

Kulcsszavak: aortastenosis, transzkatéteres billentyúimplantáció

\section{The first 200 transcatheter aortic valve implantations in the Gottsegen György Institute of Cardiology, Hungary}

Introduction: Transcatheter aortic valve implantation is a therapeutic alternative for contraindicated and high surgical risk patients with severe symptomatic aortic stenosis. This intervention is part of daily routine in the Institute of the authors. Aim: In the present work the results of the first 200 patients are discussed. Method: Until January, 2016, 200 patients (female 55\%, mean age 79.9 years, average EuroSCORE 19.3\%, left ventricular ejection fraction $54 \%$, peak gradient $81.2 \mathrm{mmHg}$, mean aortic gradient $50.9 \mathrm{mmHg}$ ) underwent transcatheter aortic valve implantation. Results: The procedure was performed with $99 \%$ success rate. Complications were evaluated according to VARC 2 definitions. Mortality was $5 \%$ at one month and $17.4 \%$ at one year. Cardiac mortality was 13.6 at one year. Cerebrovascular complications were $5 \%$ within one year, and $95 \%$ of patients were in NYHA I or II functional classes at one year. Conclusion: These findings are consistent with worldwide results.

Keywords: aortic stenosis, transcatheter aortic valve implantation

Fontos, G., Dékány, G., Hegedüs, N., Piróth, Zs., Chaurasia, A. K., Pál, M., Mandzák, A., Takács, V., Varga, A., Kovács, A., Szabó, Gy., Andréka, P. [The first 200 transcatheter aortic valve implantations in the Gottsegen Gyorgy Institute of Cardiology, Hungary]. Orv. Hetil., 2016, 157(45), 1786-1792.

(Beérkezett: 2016. július 31.; elfogadva: 2016. szeptember 1.) 


\section{Rövidítések}

AS = aortastenosis; BAV = (ballon aortic valvuloplasty $)$ ballonos aortabillentyü-tágítás; DA $=$ (direct aortic) direkt aorticus; PARTNER = Placement of Aortic Transcatheter Valve; PVL = (paravalvular aortic leak) paravalvularis aortainsufficientia; SAVR = (surgival aortic valve replacement $)$ sebészi aortabillentyü-csere; SURTAVI = Surgical Replacement and Transcatheter Aortic Valve Implantation; TA $=$ (transapical) transapicalis; TAVI $=$ (transcatheter aortic valve implantation $)$ transzkatéteres aortabillentyü-implantáció; $\mathrm{TF}=($ transfemoral $)$ transfemoralis

A fejlett világban a kalcifikálódott aortastenosis (AS) a leggyakoribb billentyübetegség, az életkor előrehaladtával prevalenciája fokozatosan nő $[1,2]$. Az első tünetek megjelenésekor, tipikusan 70-75 éves korban, a betegség prognózisa rossz. Korábban évtizedekig ennek a betegségnek az egyetlen gyógymódja a sebészi billentyúcsere (surgical aortic valve replacement - SAVR) volt. Azonban az időskorban felfedezett tünetes AS gyakran az elfogadhatatlanul magas mütéti kockázat miatt gyógyíthatatlan betegségnek számított, az ilyen betegeink nagy részét 1-2 éven belül elveszítettük [3]. Az intervenciós kardiológia fejlődése következtében, számos állatkísérletet követően, Alain Cribier 2002-ben sikeresen elvégezte az első humán transzkatéteres aortabillentyü-implantációt (TAVI) [4]. Azóta ez a módszer robbanásszerú fejlődésen ment keresztül. A PARTNER vizsgálat volt az első nagy esetszámú, randomizált, multicentrikus, kontrollált, prospektív vizsgálat, amelyben a TAVI superiornak bizonyult a konzervatív terápiával összehasonlítva [5]. A magas perioperatív mütéti kockázattal jellemzett betegek esetében elvégzett TAVI pedig noninferiornak bizonyult az SAVR-rel összehasonlítva [6]. Napjainkban a világ számos helyén, köztük intézetünkben is, ezen beavatkozás a mindennapi rutin részévé vált. Vizsgálatok, illetve számos nemzetközi regiszter adatai alapján a magas mútéti kockázattal jellemzett betegek esetében a TAVI bizonyítottan biztonságos és legalább középhosszú távon is hatásos beavatkozásnak számít [7-12]. Világszerte a TAVI-k száma meghaladja a 100 000-et, és ez a szám az elérhető új eszközökkel és a rendelkezésünkre álló egyre nagyobb tapasztalattal napról napra nő.

Az Európai Kardiológus Társaság jelenleg érvényben lévő 2012-es, billentyúbetegségekre vonatkozó ajánlása alapján súlyos, panaszos aortastenosisban szenvedő beteg esetében, ha SAVR már nem jön szóba és a billentyübetegségtől eltekintve a várható élettartam egy éven felüli, akkor TAVI javasolt (IB). TAVI megfontolandó az operálható, de magas perioperatív mütéti kockázattal jellemzett, súlyos tünetes AS-ben szenvedő beteg esetében is $(\mathrm{IIaB})$. Az ajánlás külön hangsúlyozza a heart team és a szívsebészeti háttér jelentőségét [13].

\section{Módszer}

Hazánkban elsőként a Gottsegen György Országos Kardiológiai Intézetben végeztünk TAVI-beavatkozásokat
2008 novemberében, és intézetünk ez irányú tevékenysége a technika hazai bevezetésének és elterjesztésének az alapját képezte [14]. Az első TAVI-beavatkozáson átesett betegeink azóta is jól vannak, rendszeresen kontrolláljuk őket ambulanciánkon. A kezdeti nehézségek legyőzését követően TAVI-programunk, amely napjainkban intézetünk egyik kiemelt jelentőséggel bíró profilja, 2012-ben indult be és 2016. január 11-ig összesen 201 beteg esetében 200 sikeres perkután aortabillentyüimplantáció történt. Az eddigi két sikertelen beavatkozás közül egy betegnél a vezetődrót felvezetése közben kamrafibrilláció és keringés-összeomlás alakult ki, hosszas resuscitatio után a beteget elveszítettük. A másik betegbe a 18 Fr-es sheath transfemoralis felvezetése az ér kis átmérôje miatt sikertelen volt, azóta a beteg sikeres transapicalis TAVI-ban részesült. Egy beteg esetében minithoracotomiából direkt aorticus behatolással végzett TAVI mellett hibrid megoldásként egy ülésben off-pump LIMA graft felvarrása történt a bal leszálló koszorúérre.

Intézetünkben a mútéti indikáció felállítása a klinikum és az echokardiográfiás paraméterek (billentyứn mérhető átlaggradiens >40 Hgmm, csúcsgradiens >60 Hgmm, billentyüarea $<1 \mathrm{~cm}$, vagy a testfelszínre számolt billentyüarea $<0,6 \mathrm{~cm}^{2} / \mathrm{m}^{2}$, low flow/low gradient AS esetén pedig pozitív stressz echo) alapján történik. A betegek TAVI-ra történő elfogadása minden esetben a mútéti kontraindikáció vagy az elfogadhatatlanul magas mútéti kockázat alapján történik, és ez a heart team felelőssége, amelynek tagjai kötelezően a beteg kezelőorvosa, billentyưimplantációban jártas intervenciós kardiológus, szívsebész, aneszteziológus, illetve képalkotó szakember (echo, CT). A billentyưimplantációt stabil állapotban lévő beteg esetében az aktuális várólista alapján végezzük el, állapotromlás esetében azonban - szigorú egyedi döntés után - a beavatkozás a klinikumtól függő sürgősséggel történik meg. Akut esetben a billentyű azonnali ballonos tágítását (BAV) „bridge to szívmütét”, vagy gyakrabban „bridge to TAVI” indikációval végezzük el.

\section{Eredmények}

\section{Betegek jellemzői}

200, TAVI-ban részesülő betegünk közül 110 nő (55\%), 90 férfi (45\%), átlagéletkoruk 79,9 $\pm 5,9$ év (66-93 év között) volt. Minden beteg esetében intézetünkben is végeztünk echokardiográfiát, amely alapján az átlagos ejekciós frakció $54 \pm 17,3 \%$-nak adódott. A súlyos AS diagnózisát az aortabillentyün mérhetô csúcsgradiens $(81,2 \pm 26,7 \mathrm{Hgmm})$, átlaggradiens $(50,9 \pm 17,1$ Hgmm) és kalkulált billentyúarea $\left(0,54 \pm 0,15 \mathrm{~cm}^{2}\right)$ alapján állítottuk fel, 81 betegnek $(40,5 \%)$ volt balkamra-diszfunkciója $(\mathrm{EF}<50 \%)$. Betegeink többsége idős multimorbid populációból származott, a beavatkozás előtt 117 betegünk $(58,5 \%)$ rossz funkcionális állapotban (NYHA III-IV) volt. Az átlagos Logistic EuroSCORE (European System for Cardiac Operative Risk Evalution) 
1. táblázat

Betegeink karakterisztikája és társbetegségei

\begin{tabular}{|c|c|c|c|}
\hline \multicolumn{4}{|c|}{ A betegek karakterisztikája $(\mathrm{n}=200)$} \\
\hline \multicolumn{3}{|l|}{ Átlagéletkor } & $79,9 \pm 5,9$ év \\
\hline \multirow[t]{2}{*}{ Nem } & \multicolumn{2}{|l|}{ Férfi } & $90(45 \%)$ \\
\hline & \multicolumn{2}{|l|}{ Nő } & $110(55 \%)$ \\
\hline \multirow[t]{4}{*}{$\mathrm{ECHO}$} & \multicolumn{2}{|l|}{$\mathrm{EF}$} & $54 \pm 17,3 \%$ \\
\hline & \multicolumn{2}{|l|}{ Csúcsgradiens } & $\begin{array}{l}81,2 \pm 26,7 \\
\mathrm{Hgmm}\end{array}$ \\
\hline & \multicolumn{2}{|l|}{ Átlaggradiens } & $\begin{array}{l}50,9 \pm 17,1 \\
\mathrm{Hgmm}\end{array}$ \\
\hline & \multicolumn{2}{|l|}{ Area } & $\begin{array}{l}0,54 \pm 0,15 \\
\mathrm{~cm}^{2}\end{array}$ \\
\hline \multicolumn{3}{|c|}{ Rossz funkcionális állapot (NYHA III-IV) } & $117(58,5 \%)$ \\
\hline \multicolumn{3}{|c|}{ Logisztikus EuroSCORE } & $19,3 \pm 11,6 \%$ \\
\hline \multirow[t]{21}{*}{ Társbetegségek } & \multicolumn{2}{|l|}{ Hypertonia } & $176(88 \%)$ \\
\hline & \multicolumn{2}{|l|}{ Diabetes } & $65(32,5 \%)$ \\
\hline & \multicolumn{2}{|l|}{ Pitvarfibrilláció } & $79(39,5 \%)$ \\
\hline & \multicolumn{2}{|l|}{ Coronariabetegség } & $144(72 \%)$ \\
\hline & \multicolumn{2}{|l|}{ Korábbi PCI } & $56(28 \%)$ \\
\hline & \multicolumn{2}{|l|}{ Korábbi CABG opus } & $31(15,5 \%)$ \\
\hline & \multicolumn{2}{|l|}{ Korábbi LIMA graft } & $26(13 \%)$ \\
\hline & \multicolumn{2}{|l|}{ Korábbi RIMA graft } & $1(0,5 \%)$ \\
\hline & \multicolumn{2}{|l|}{ Porcelánaorta } & $10(5 \%)$ \\
\hline & \multicolumn{2}{|l|}{ Korábbi BAV } & $30(15 \%)$ \\
\hline & \multicolumn{2}{|c|}{ Korábbi PM-implantáció } & $24(12 \%)$ \\
\hline & \multicolumn{2}{|c|}{ Aortamúbillentyú-implantáció } & $6(3 \%)$ \\
\hline & \multicolumn{2}{|c|}{ Mitrálismúbillentyú-implantáció } & $2(1 \%)$ \\
\hline & \multicolumn{2}{|c|}{ Alsó végtagi verőérbetegség } & $17(8,5 \%)$ \\
\hline & \multicolumn{2}{|l|}{ Carotisbetegség } & $56(28 \%)$ \\
\hline & \multirow{2}{*}{$\begin{array}{l}\text { Cerebrovascularis } \\
\text { történés }\end{array}$} & TIA & $11(5,5 \%)$ \\
\hline & & STROKE & $14(7 \%)$ \\
\hline & \multicolumn{2}{|l|}{ COPD } & $42(21 \%)$ \\
\hline & \multicolumn{2}{|l|}{ Pulmonalis embolia } & $5(2,5 \%)$ \\
\hline & \multicolumn{2}{|l|}{$\begin{array}{l}\text { Krónikus } \\
\text { veseelégtelenség }\end{array}$} & $42(21 \%)$ \\
\hline & Bechterew & & $5(2,5 \%)$ \\
\hline
\end{tabular}

19,3 \pm 11 ,6\%-nak adódott, míg abszolút mútéti kontraindikációt jelentő porcelánaorta 10 betegnél $(5 \%)$ fordult elő. Korábbi pacemaker- (PM-) implantáció 24 betegnél $(12 \%)$ történt, coronariabetegség 144 beteg (72\%) anamnézisében szerepelt, közülük 56 részesült (28\%) korábbi PCI-ben, illetve 31 beteg $(15,5 \%)$ esetében pedig coronaria-bypassmútét (CABG) történt. Korábban $\mathrm{BAV}$-ot 30 beteg esetében (15\%) végeztünk, a további betegjellemzők az 1. táblázatban láthatók.

\section{A beavatkozás}

Első lépésként a betegeket egy jól strukturált kivizsgálási protokollnak vetettük alá, amelynek célja az indikáció felállítása után a kivitelezhetőség megítélése, valamint a szükséges billentyúméret megállapítása volt. A panaszok meghatározása, a fizikális vizsgálat, illetve egy általános laboratóriumi vizsgálat után transthoracalis echokardiográfiát végeztünk az aortastenosis szignifikanciájának, az anulus méretének, a szisztolés balkamra-funkciónak, valamint az esetleges egyéb billentyúhibák meglétének a megítélésére. Ezután koronarográfia, aortográfia, valamint mindkét oldali arteria femoralis-iliaca, esetleg arteria subclavia angiográfiája történt, majd utolsó lépésként EKG-kapuzott multislice CT-angiográfiát végeztünk az anulus körüli struktúrákról, valamint EKG-kapuzás nélküli vizsgálatot az arteria femoralis-iliaca, az aorta descendens és ascendens rendszerröl. Speciális szoftverrel (3mensio, Pie Medical Imaging B.V., Maastricht, Hollandia), a CT-vizsgálat alapján készült 3 dimenziós rekonstrukció segítségével döntöttünk a behatolási kapuról és a megfelelő billentyúméretről ( 1 . ábra). A beavatkozások közül 187-et az arteria femoralison (TF) keresztül végeztük $(93,5 \%)$, míg direkt aorticus (DA) implantációra 5 betegnél $(2,5 \%)$ került sor, és 8 esetben (4\%) a szívcsúcs felól, transapicalis (TA) implantációt végeztünk. A beavatkozásokat eleinte általános anesztéziában hajtottuk végre, de az utóbbi idóben szinte teljesen áttértünk az éber betegen végzett analgoszedáció alkalmazására. Eleinte a TF TAVI-kat is szinte minden esetben érsebészeti feltárás, majd zárás mellett végeztük, később a perkután punkció és záróeszközök használatára tértünk át. Eleinte a ProStar (Abbott Vascular, Menlo Park, CA), később a ProGlide (Abbott Vascular, Menlo Park, CA) perkután femoralis záróeszközöket használtunk. A billentyútípusok közül TA-behatolás során 2 alkalommal a ballonnal expandálható Edwards SAPIEN XT (Edwards Lifesciences, Inc., Irvine, CA) billentyút, illetve 6 esetben az öntáguló nitinolvázból álló és karjai segítségével a valsalvatasakokba támaszkodó Engager (Medtronic, Inc., Minneapolis, MN) billentyúket implantáltunk. DA-, illetve TF-behatolásból összesen 175 öntáguló nitinolvázból és sertéspericardiumból álló Medtronic CoreValve (Medtronic, Inc., Minneapolis, $\mathrm{MN}$ ) billentyút használtunk. A második generációs billentyúk közül a CoreValve/Evolut R teljesen visszahúzható és repozicionálható billentyúbool 14-et használtunk, illetve 3 alkalommal került sor a Boston Scientific szintén repozicionálható és nitinolvázból álló LotusValve (Boston Scientific, Marlborough, MA) elnevezésú billentyújének implantációjára. A billentyúimplantáció előtt 163 esetben $(81,5 \%)$ végeztünk ballonos előtágítást. Az implantációt követően a billentyú megfelelő pozícióját transoesophagealis echokardiográfíával, illetve aortográfiával ellenőriztük. A paravalvularis insufficientia (PVL) gondos értékelésére nagy hangsúlyt fektettünk, ugyanis mára már egyértelmúvé vált, hogy az implantációt követően egyből jelentkező közepes vagy súlyosabb paravalvularis regurgitatio esetén a betegek prognózisa rossz [15-17]. Ugyanakkor az is bizonyítottá vált, hogy az öntáguló CoreValve/Evolut R billentyú implantációja 


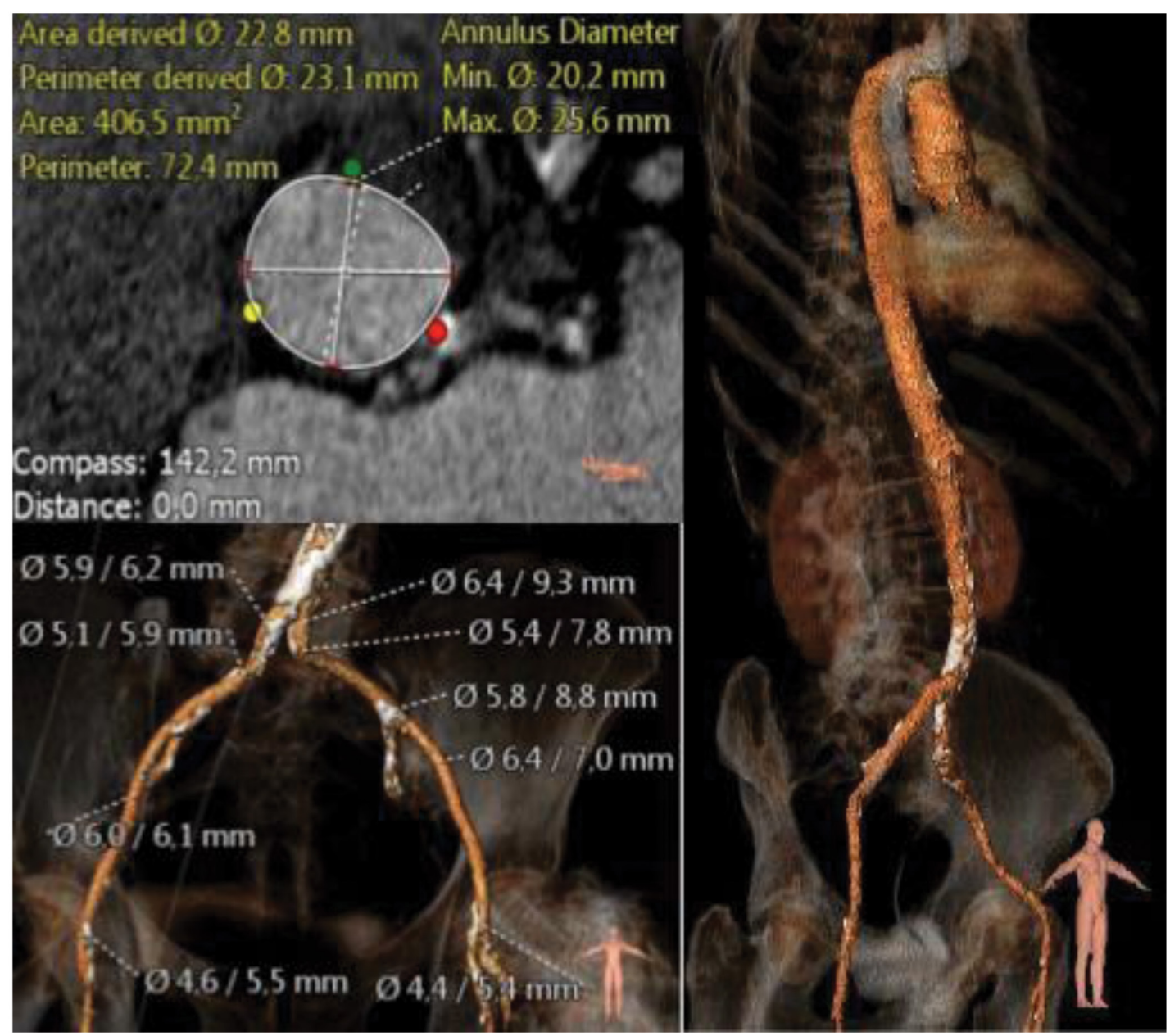

1. ábra

Az angió CT alapján készült rekonstrukciós képek. Bal oldalon felül az aorta anulus keresztmetszeti képe és a billentyúméret kiválasztásához használatos mérések. Bal oldalon lent a potenciális behatolási kapuk méretezése és anatómiája, jobb oldalon az implantáció szempontjából releváns teljes érrendszer 3 dimenziós rekonstrukciója

utáni PVL idővel csökken [18]. Szuboptimális eredmény miatt 55 esetben $(27,5 \%)$ ballonos utótágítást végeztünk, a billentyű pozíciójának módosítását snare katéterrel 12 alkalommal (6\%) kíséreltük meg, második billentyưimplantációra 5 alkalommal $(2,5 \%)$ került sor. „Valve in valve" implantációt jelentős korábbi aortabioprotézisstenosis miatt 7 esetben (3,5\%) végeztünk (2. ábra).

\section{Kimenetel}

A TAVI-t követően 3 alkalommal $(1,5 \%)$ került sor nyitott szívmütétre, kétszer tamponád miatt, egy alkalommal pedig a katéterbillentyưt kioldó szerkezet hibája folytán a billentyű nem vált le a felvezetőrendszerról. Az első 30 nap során 10 beteget (5\%) veszítettünk el. Eddig 132 betegnek zárult le az egyéves utánkövetése, az egyéves összmortalitás 17,4\%-nak (23 beteg), a kardiális mortalitás pedig 13,6\%-nak (18 beteg) adódott. A TAVI-t követően az intézetünkben töltött napok száma az emisszióig átlag $12,5 \pm 6,8$ nap volt. A szövődményeink feldolgozása a The Valve Academic Research Consortium-2 (VARC-2) szerint történt [19]. A poszt- operatív szakban 46 új PM-implantáció történt $(26,1 \%)$ magas fokú vagy komplett AV-blokk, illetve szignifikáns bradycardia miatt. Periproceduralis infarktus 4 alkalommal (2\%) jelentkezett, egy alkalommal „valve in valve” implantáció során a fötörzs orifitiuma fedésbe került, egy másik alkalommal a domináns jobb coronaria occludalt, egyszer pedig a nem szokványosan a jobb coronariás tasakból eredő CX thromboticus occlusiója következett be, továbbá egy alkalommal főtörzs-LAD-dissectio alakult ki. Az utolsó esetet kivéve, amelyet perkután sikeresen elláttunk, a betegeket, sajnos, elveszítettük. Súlyos mechanikus szövődmény (aortadissectio, anulusruptura) nem fordult elő. A beavatkozást követő egy év során öszszesen 10 cerebrovascularis történés volt (5\%), ebből 6 major stroke $(3 \%)$. A perioperatív időszakban vascularis szövődmény 20 alkalommal (10\%) jelentkezett, érsebészeti beavatkozásra 7 alkalommal $(3,5 \%)$ volt szükség, végtagelvesztés nem történt. Szignifikáns vérzést 26 beteg esetében (13\%) észleltünk, míg a posztoperatív szakban 53 beteg $(26,5 \%)$ részesült szövődménymentes transzfúzióban. Akut veseelégtelenség 5 betegnél $(2,5 \%)$ 


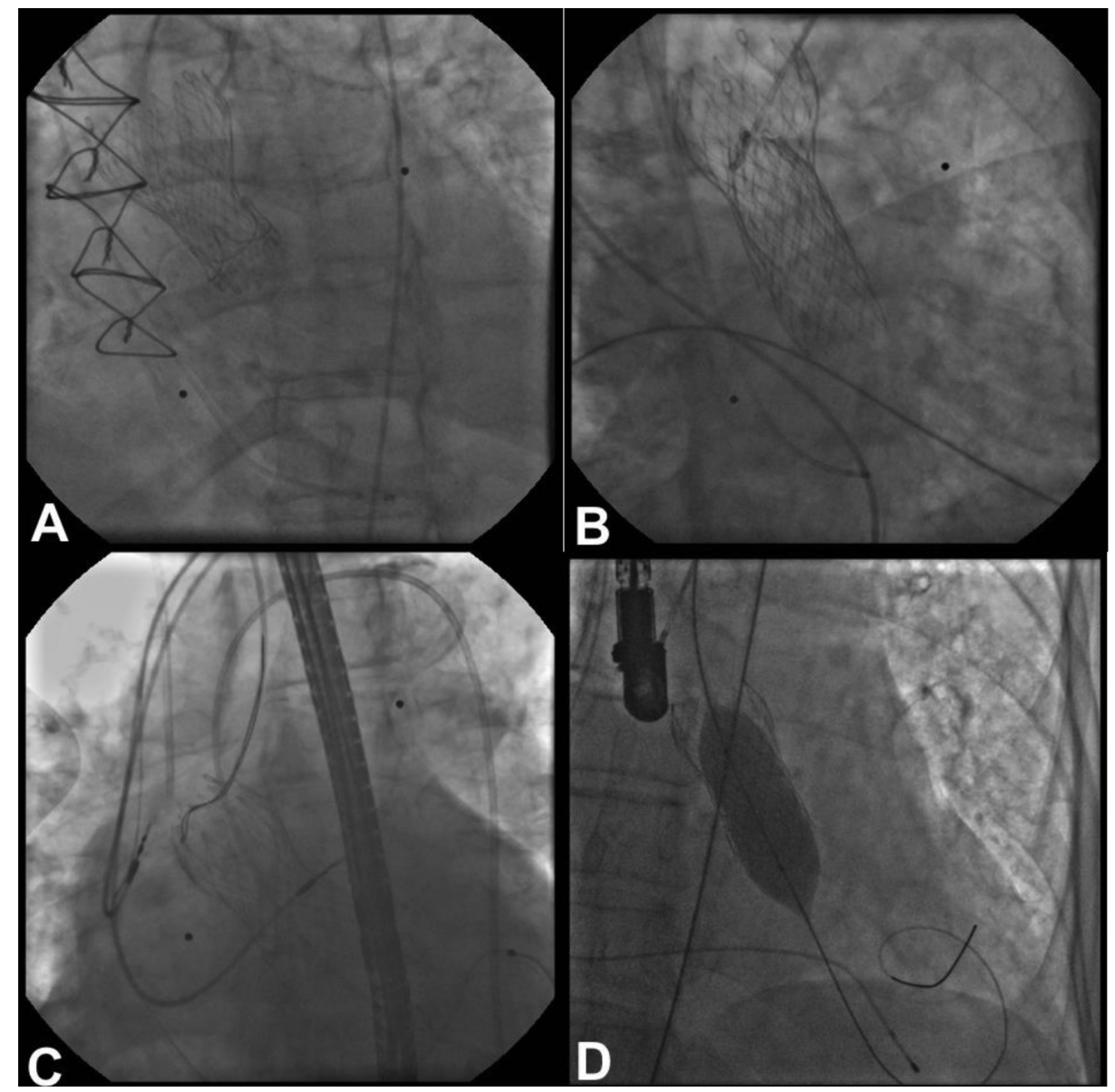

2. ábra

A) Korábbi bioprotézisbe implantált TAVI-billentyú. B) Az első billentyű suboptimális pozíciója miatt 2. TAVI-billentyút implantáltunk. C) A billentyü pozíciójának modifikálása snare katéterrel. D) A TAVI-billentyú ballonos utótágítása

jelentkezett. A TAVI-t követően manifeszt szívelégtelenséget 11 beteg esetében (5,5\%) észleltünk (2. táblázat).

Az egyéves echokardiográfiás kontroll eddig 89 beteg esetében történt meg, amely során az átlagos ejekciós frakció $58,1 \% \pm 11,3$, az átlagos csúcsgradiens $15,1 \pm 7,4$ Hgmm, míg az átlaggradiens 9,4 \pm 4,8 Hgmm-nek adódott. Az egyéves kontroll során összesen 5 betegnél tapasztaltunk közepes PVL-t. Egyéves kontrollon 102 beteg jelent meg, közülük összesen 5-en voltak rossz (NYHA III-IV) funkcionális állapotban.

\section{Megbeszélés}

Napjainkra a TAVI a mindennapi rutin részévé vált, ma már teljesen elfogadott és egyre szélesebb körben használt kezelési formája a sebészi kontraindikációval vagy magas mútéti kockázattal bíró súlyos, panaszos AS-ben szenvedő betegeknek. A közepes mútéti kockázattal jellemzett betegek esetében azonban a TAVI szerepe ma még kérdéses. A noninferiotity tervezésú PARTNER-2 vizsgálat ugyan bizonyította, hogy ebben a betegcsoportban nincs szignifikáns különbség az Edwards SAPIEN XT ballonnal feltágítható billentyüvel elvégzett TAVIbeavatkozáson és a sebészi billentyứcserén átesett bete-
2. táblázat | Komplikációk és mortalitás

\begin{tabular}{|c|c|c|c|}
\hline Komplikációk & \multicolumn{2}{|c|}{ Sikertelen implantáció } & $2(1 \%)$ \\
\hline & \multicolumn{2}{|l|}{ Mellkasmegnyitás } & $3(1,5 \%)$ \\
\hline & \multicolumn{2}{|l|}{ Anulusruptura } & 0 \\
\hline & \multicolumn{2}{|c|}{ Periproceduralis AMI } & $4(2 \%)$ \\
\hline & \multicolumn{2}{|c|}{ Cerebrovascularis történés } & $10(5 \%)$ \\
\hline & \multicolumn{2}{|l|}{ Major stroke } & $6(3 \%)$ \\
\hline & \multicolumn{2}{|l|}{ Transzfúzió } & $53(26,5 \%)$ \\
\hline & \multicolumn{2}{|l|}{ Vérzés } & $26(13 \%)$ \\
\hline & \multicolumn{2}{|c|}{ Vascularis szövődmény } & $20(10 \%)$ \\
\hline & \multicolumn{2}{|c|}{ Érsebészeti beavatkozás } & $7(3,5 \%)$ \\
\hline & \multicolumn{2}{|l|}{ Végtag elvesztése } & 0 \\
\hline & \multicolumn{2}{|c|}{$\begin{array}{l}\text { PM-implantáció TAVI után } \\
(\mathrm{n}=200-24)\end{array}$} & $46(26,1)$ \\
\hline & \multicolumn{2}{|l|}{ Szívelégtelenség } & $11(5,5 \%)$ \\
\hline & \multicolumn{2}{|l|}{ Tamponád } & $3(1,5 \%)$ \\
\hline \multirow[t]{3}{*}{ Mortalitás } & 1 hónap & Összmortalitás & $10(5 \%)$ \\
\hline & \multirow[t]{2}{*}{1 éves $(n=132)$} & Összmortalitás & $23(17,4 \%)$ \\
\hline & & $\begin{array}{l}\text { Kardiális } \\
\text { mortalitás }\end{array}$ & $18(13,6 \%)$ \\
\hline
\end{tabular}




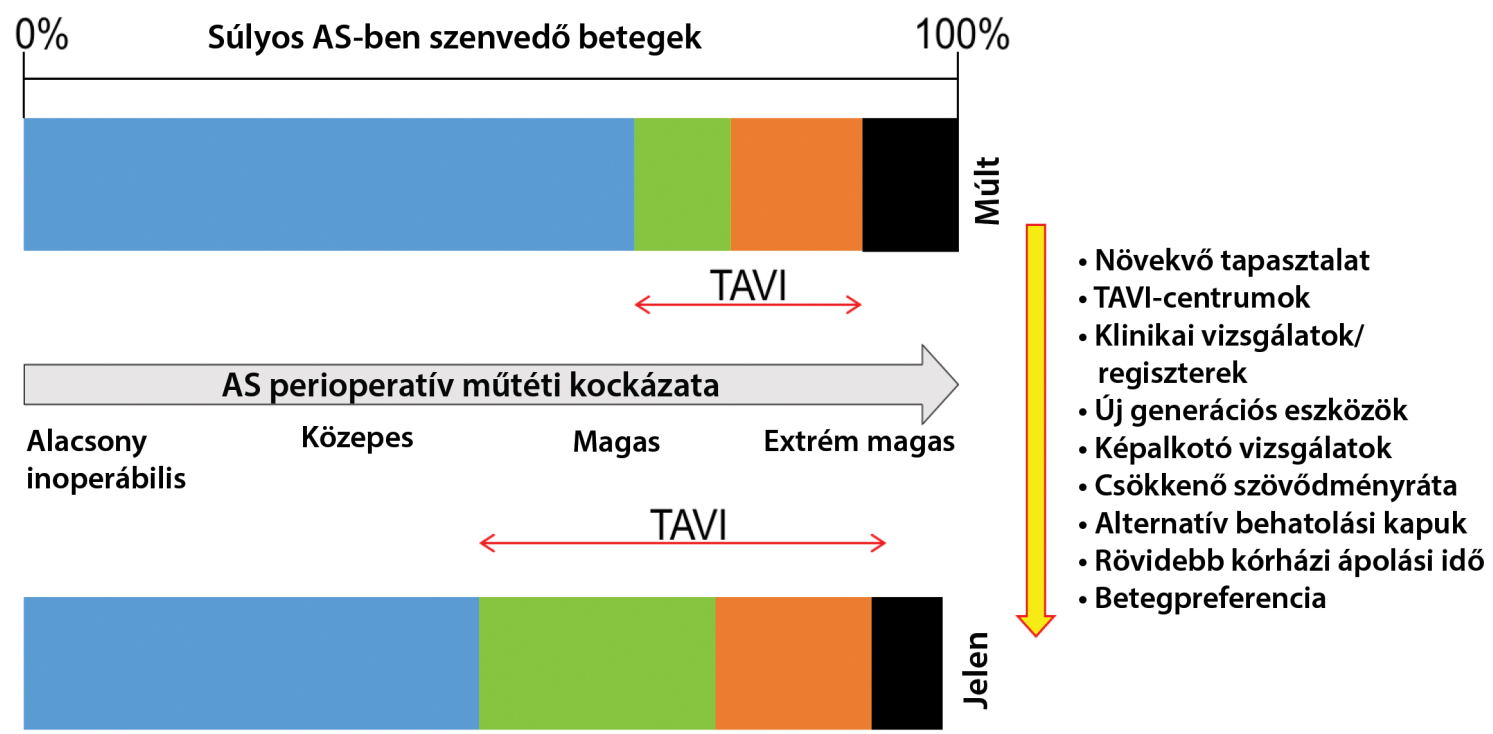

SAVR végzendő Heart team döntés: TAVI vs. SAVR TAVI végzendő SAVR/TAVI már nem jön szóba

3. ábra Súlyos AS-ben szenvedó betegek perioperatív kockázata, TAVI vs. ASVR megítélés múltja és jelene
AS = aortastenosis; SAVR = (surgical aortic valve replacement) sebészi aortabillentyú-csere

gek esetében a teljes mortalitás és a rokkantságot okozó stroke kompozit végpontban a második év végén [20]. Az öntáguló CoreValve billentyúvel közepes mútéti kockázatú betegek esetében elvégzett TAVI-t a SURTAVI tanulmányban vizsgálják, az eredményeket a jövő évre várjuk. Néhány kisebb esetszámú vizsgálat elindult már alacsony mütéti kockázatú betegekkel is [21, 22]. Természetesen nem gondoljuk, hogy a TAVI jelenlegi helyzete komolyan veszélyeztetné az aortabillentyű mütéti cseréjének létjogosultságát, az azonban már most is világosan látható, hogy a TAVI átírta a sebészi aortabillentyư-beültetés helyét a súlyos, panaszos AS kezelésében (3. ábra).

Hazánkban az első TAVI-beültetés 2008 novemberében történt a Gottsegen György Országos Kardiológiai Intézetben, és a mai napig intézetünkben végezzük a legmagasabb számban ezt a beavatkozást. Jelenleg a TAVI-beültetések számát csupán a financiális tényezők limitálják. Heart team konszenzus alapján ma körülbelül 150 beteg vár a beavatkozásra intézetünkben. Ezeknek a betegeknek a hagyományos sebészi billentyücseréje a sebészi kontraindikáció vagy az extrém magas perioperatív kockázat miatt nem jön szóba.

Jelen munkánkban az intézetünkben elvégzett első 200 TAVI eredményeiről számolunk be. Mindez alátámasztja, hogy a TAVI nálunk is magas sikeraránnyal és alacsony szövődményrátával végezhető, továbbá eredményeink nem térnek el lényegesen a nagy nemzetközi vizsgálatok, illetve regiszterek eredményeitől. A szerzők tudomása szerint ez az első hazai TAVI-regiszteradatokat bemutató közlemény.
Anyagi támogatás: A közlemény megírása anyagi támogatásban nem részesült.

Szerzői munkamegosztás: F. G., A. P.: A beavatkozások döntő többségét első vagy másodoperatőrként végezték. D. G.: A beavatkozások aktív segítése, a betegregiszter vezetése, a közlemény megszövegezése. H. N.: A beavatkozások döntő többségének vezetése asszisztensi oldalról, valamint aktív segítség a statisztikai számítások elvégzésében. P. Zs., A. K. C., Sz. Gy.: A beavatkozások egy részének végzése első vagy másodoperatőrként. P. M.: A beavatkozások során az echokardiográfiás vizsgálatok elvégzése. M. A.: A beteg regisztervezetése, betegek utánkövetése. T. V.: A CT alapján rekonstrukciós mérések készítése, a Medtronic cég által forgalmazott billentyütípusok esetén a beavatkozások aktív segítése. V. A., K. A.: A beavatkozások anesztéziájának vezetése.

Érdekeltségek: Takács Viktor a Medtronic Hungaria Kft. alkalmazottja. Dr. Fontos Géza és dr. Andréka Péter a Medtronic Hungaria Kft. szerződött partnerei, időszakosan a cég megbízásából nemzetközi proktorációt és oktatótevékenységet végeznek.

\section{Irodalom}

[1] Go, A. S., Mozaffarian, D., Roger, V. L., et al.: Heart disease and stroke statistics - 2013 update. A report from the American Heart Association. Circulation, 2013, 127(1), e6-e245.

[2] Iung, B., Baron, G., Butchart, E. G., et al.: A prospective survey of patients with valvular heart disease in Europe: The Euro Heart Survey on valvular heart disease. Eur. Heart J., 2003, 24(13), 1231-1243. 
[3] Iung, B., Cachier, A., Baron, G., et al.: Decision-making in elderly patients with severe aortic stenosis: Why are so many denied surgery? Eur. Heart J., 2005, 26(24), 2714-2720.

[4] Cribier, A., Eltchaninoff, H., Bash, A., et al.: Percutaneous transcatheter implantation of an aortic valve prosthesis for calcific aortic stenosis: first human case description. Circulation, 2002, 106(24), 3006-3008.

[5] Leon, M. B., Smith, C. R., Mack, M., et al.: Transcatheter aorticvalve implantation for aortic stenosis in patients who cannot undergo surgery. N. Engl. J. Med., 2010, 363(17), 1597-1607.

[6] Smith, C. R., Leon, M. B., Mack, M. J., et al.: Transcatheter versus surgical aortic-valve replacement in high-risk patients. N. Engl. J. Med., 2011, 364(23), 2187-2198.

[7] Moat, N. E., Ludman, P., De Belder, M. A., et al.: Long-term outcomes after transcatheter aortic valve implantation in highrisk patients with severe aortic stenosis: The U.K. TAVI (United Kingdom Transcatheter Aortic Valve Implantation) registry. J. Am. Coll. Cardiol., 2011, 58(20), 2130-2138.

[8] Gilard, M., Eltchaninoff, H., Iung, B., et al.: Registry of transcatheter aortic-valve implantation in high-risk patients. N. Engl. J. Med., 2012, 366(18), 1705-1715.

[9] Di Mario, C., Eltchaninoff, H., Moat, N., et al.: The 2011-12 pilot European Sentinel Registry of Transcatheter Aortic Valve Implantation: In-hospital results in 4,571 patients. EuroIntervention, 2013, 8(12), 1362-1371.

[10] Adams, D. H., Popma, J. J., Reardon, M. J., et al.: Transcatheter aortic-valve replacement with a self-expanding prosthesis. N. Engl. J. Med., 2014, 370(19), 1790-1798.

[11] Reardon, M. J., Adams, D. H., Kleiman, N. S., et al.: 2-year outcomes in patients undergoing surgical or self-expanding transcatheter aortic valve replacement. J. Am. Coll. Cardiol., 2015, 66(2), 113-121.

[12] Schymik, G., Würth, A., Bramlage, P., et al.: Long-term results of transapical versus transfemoral TAVI in a real world population of 1000 patients with severe symptomatic aortic stenosis. Circ. Cardiovasc. Interv., 2015, $8(1)$, e000761.

[13] Vahanian, A., Alfieri, O., Andreotti, F., et al.: Guidelines on the management of valvular heart disease (version 2012). Eur. Heart J., 2012, 33(19), 2451-2496.

[14] Fontos, G., Piróth, Z., Szöke, S., et al.: The first percutaneous aortic valve implantation in Hungary. [Az első perkután aortabillentyú- beültetés Magyarországon.] Orv. Hetil., 2009, 150(9), 387396. [Hungarian]

[15] Sinning, J. M., Hammerstingl, C., Vasa-Nicotera, M., et al.: Aortic regurgitation index defines severity of peri-prosthetic regurgitation and predicts outcome in patients after transcatheter aortic valve implantation. J. Am. Coll. Cardiol., 2012, 59(13), 11341141.

[16] Sinning, J. M., Vasa-Nicotera, M., Chin, D., et al.: Evaluation and management of paravalvular aortic regurgitation after transcatheter aortic valve replacement. J. Am. Coll. Cardiol., 2013, 62(1), $11-20$.

[17] Ali, O. F., Schultz, C., Jabbour, A., et al.: Predictors of paravalvular aortic regurgitation following self-expanding Medtronic CoreValve implantation: The role of annulus size, degree of calcification, and balloon size during pre-implantation valvuloplasty and implant depth. Int. J. Cardiol., 2015, 179, 539-545.

[18] Oh, J. K., Little, S. H., Abdelmoneim, S. S., et al.: Regression of paravalvular aortic regurgitation and remodeling of self-expanding transcatheter aortic valve. An observation from the CoreValve U.S. Pivotal Trial. JACC Cardiovasc. Imaging, 2015, $8(12), 1364-1375$

[19] Kappetein, A. P., Head, S. J., Généreux, P., et al.: Updated standardized endpoint definitions for transcatheter aortic valve implantation. J. Am. Coll. Cardiol., 2012, 60(15), 1438-1454.

[20] Leon, M. B., Smith, C. R., Mack, M. J., et al.: Transcatheter or surgical aortic-valve replacement in intermediate-risk patients. N. Engl. J. Med., 2016, 374(17), 1609-1620.

[21] Barbash, I. M, Finkelstein, A., Barsheshet, A., et al.: Outcomes of patients at estimated low, intermediate, and high risk undergoing transcatheter aortic valve implantation for aortic stenosis. Am. J. Cardiol., 2015, 116(12), 1916-1922.

[22] Waksman, R.: TAVR for patients with low risk for mortality is here for investigation. Cardiovasc. Revasc. Med., 2016, 17(1), $1-2$.

\section{A rendezvények és kongresszusok híranyagának leadása}

a lap megjelenése előtt legalább 40 nappal lehetséges, a 6 hetes nyomdai átfutás miatt. Kérjük megrendelőink szíves megértését.

A híranyagokat a következő címre kérjük:

Orvosi Hetilap titkársága: Budai.Edit@akkrt.hu Akadémiai Kiadó Zrt. 